\section{Journal of Computer Networks, Architecture and High Performance Computing}

Volume 3, Number 2, July 2021

https://doi.org/10.47709/cnahpc.v3i2.1026
Submitted : 12 July 2021

Accepted : 24 July 2021

Published : 27 August 2021

\title{
Design of Expert System for Diagnosis of Gonorrhea Disease by using Web- Based Naïve Bayes Method
}

\author{
Teri Ade Putra1 ${ }^{*}$, Raja Ayu Mahessya ${ }^{2)}$, Pradani Ayu Widya Purnama ${ }^{3)}$, Reza Suriadinata ${ }^{4)}$ \\ 1)23)4)Universitas Putra Indonesia "YPTK" Padang, Indonesia \\ ${ }^{1}$ teriputra2@gmail.com, ${ }^{2}$ ayumahessya@upiyptk.com, ${ }^{3)}$ pradaniwid@gmail.com,,${ }_{-}^{4}$ rezasuridinata6@gmail.com
}

\begin{abstract}
Gonorrhea is a sexually transmitted disease caused by the bacterium Neisseria gonorrhea that infects the lining of the bladder, cervix, rectum, throat, and the whites of the eyes. This disease is spread through the bloodstream to other parts of the body, especially the skin and joints and is generally transmitted through sexual contact. Gonorrhea not only affects adult men and women, but babies and even newborns can get gonorrhea from their mothers. An expert system is a system that seeks to adopt human knowledge into computers, so that computers can solve problems like an expert. With this expert system, the public can obtain information or can solve the problems they face which can only be obtained with the help of experts in their fields. This study explains how the expert system diagnoses Gonorrhea using the Naïve Bayes method. By using the Naïve Bayes method, it can predict future probability values based on previous experiences experienced by people with gonorrhea, Document classification can be personalized, tailored to the needs of each person. By using this expert system application, it can provide information and make it easier for the public to be more familiar with Gonorrhea and can handle problems based on the expertise of doctors who are experts in their fields. This expert system can provide solutions and prevention of gonorrhea disease with the diagnosis process carried out efficiently and save time in helping the community in the prevention that occurs. This web-based expert system application is built with the PHP programming language and MySQL data storage.
\end{abstract}

Keywords: Expert System; Gonorrhea; Naive Bayes; Web; MySQL; PHP

\section{INTRODUCTION}

Gonorrhea in a broad sense includes all diseases caused by bacterium that can cause infection in the urethra, cervix, anus, and throat (Octiara \& Ungu, 2018). gonorrhoeae is a classic type of sexually transmitted disease (STD) caused by infection with the bacterium Neisseria gonorrhoeae which has a high incidence among sexually transmitted infections (STDs). This infection occurs widely throughout the world with a higher prevalence in developing countries including Indonesia. Gonorrhea infection can affect both men and women, where there are several types of disease, namely, Gonorrhea Urethritis, Gonorrhea Cervicitis, Gonorrhea Pharyngitis, Gonorrhea Prakitis. STI (sexually transmitted infection) causes more than 30 bacteria, viruses, parasites, fungi, and various types which are spread through sexual contact and in general this infection has asymptomatic characteristics or does not show symptoms at all (Pitasari \& Martodiharjo, 2019) Most sufferers of Gonorrhea in the genitals or intimate organs are embarrassed to consult a doctor or expert directly. By doing a diagnosis, it is expected to be able to find more in-depth information about a disease, especially the gonorrhea disease. In addition, you can find the symptoms and prevention of the disease based on the knowledge provided by the treating doctor. The purpose of this research is to produce an expert system that can diagnose gonorrhea and the benefits of research are to help the public to obtain information and find solutions to gonorrhea.

In this study, an expert system was developed for the diagnosis of Gonorrhea using the Naïve Bayes method. This method is a simple probability classification based on Bayes' theorem. The advantage of classification is that it only requires a small amount of training data to estimate the parameters (means and variance of variables) required for classification (Karunia et al., 2017) This Naïve Bayes design can be used to assist experts in classifying diseases and provide ways to overcome them. The Naïve Bayes method was chosen because this method pays attention to all

* Corresponding author

This is an Creative Commons License This work is licensed under a Creative

Commons Attribution-NoDerivatives 4.0 International License. 


\section{Journal of Computer Networks, Architecture and High Performance Computing}

Volume 3, Number 2, July 2021

https://doi.org/10.47709/cnahpc.v3i2.1026
Submitted : 12 July 2021

Accepted : 24 July 2021

Published : 27 August 2021

the features in the training data so that it makes this method optimal in carrying out the classification process and has a fairly high level of accuracy compared to other methods (Prayoga et al., 2018)

Based on the explanation above, the writer tries to conclude the title "Design of Expert System for Diagnosis of Gonorrhea Disease by using Web-Based Naïve Bayes Method".

\section{LITERATURE REVIEW}

The research conducted by R Dimas Adityo, Herti Miawarni entitled " Implementation Of Naive Bayes Classifier Algorithm To Evaluation In Utilizing Online Hotel Tax Reporting Application "Naive Bayes Classification method is one of the popular Classification Algorithm, Naive Bayes competitive Performance in the process of classification despite using the assumption of keidependenan attributes (there is no relationship between attributes). Assumption keidependenan this attribute on the data actually rarely happens, but although the assumption keidependenan atirbut masses but Naive Bayes classification performance breached quite high, this is proven on a wide range of empirical research.(Adityo \& Miawarni, 2017)

Hairani and Muhammad Innuddin in their research "Combination of Correlated Naive Bayes Method and Wrapper Feature Selection Method for Classification Health Data" The classification method used in this study is Correlated Naive Bayes algorithm. Correlated Algorithm Naive Bayes is a developed algorithm Naive Bayes. Parameters added to Correlated Naive Bayes algorithm is the correlation value between feature $\mathrm{X}$ with its class and laplacian number. Calculationcorrelation (R-Square) was performed to show the relationship between features and classes in the Correlated Naive algorithmBayes Laplacian numbers are used to avoidoccurrence of zero probability. To improve accuracy Correlated Naive Bayes algorithm can use the technique feature selection. (Hairani \& Innuddin, 2020).

Research by Bahrawi As'ad entitled "Decision Prediction Using Classification Method Naive Bayes, One-R, And Decision Tree" Naive Bayes is aclassification by method probability and statistics that

put forward by British scientists Thomas Bayes, is predicting odds in the future based on experience inthe past so it is known as Bayes' theorem. The theorem combined with "naive" where it is assumed that the conditions between the attributes are mutually free (As'ad, 2016).

Annisa Fadillah in their research entitled "Application Of Nave Bayes Classifier for Course Concentration Selection" Naive Bayes classifier which generates recommendations based on dataset calculations. One of the studies related to this research is research with the title Data Mining Using Naïve Bayes Algorithm for Classification of University Students Dian Nuswantoro. The research discusses the classification of student graduation, and the improvement as well as a decrease in student graduation, as one of the evaluation materials in determining policy (Fadillah \& Hardiyana, 2018).

Research by syarli entitled "Naive Bayes Method For Graduation Prediction (Case Study: College New Student Data)" Naïve Bayes is a classification with the method probability and statistics put forward by scientists English Thomas Bayes, i.e. predicting future opportunities future based on previous experience so that known as Bayes' theorem. The theorem combined with "naive" where the assumed condition the attributes are independent of each other. In a dataset, each row/document $\mathrm{I}$ is assumed to be a vector of values attribute $<\mathrm{x} 1, \mathrm{x} 2, \ldots, \mathrm{x} 3>$ where each value is reviewed attribute $\mathrm{Xi}(\mathrm{iC}[1, \mathrm{n}]))$. Each row has a class label ci $\{\mathrm{c} 1, \mathrm{c} 2, \ldots, \mathrm{ck}\}$ as class $\mathrm{C}$ variable values, so for do the classification can be calculated probability value $\mathrm{p}(\mathrm{C}=\mathrm{ci} \mid \mathrm{X}=\mathrm{xj})$, because in Naïve Bayes it is assumed that each attribute is independent, then the equation obtained is are as follows :

- Probability $\mathrm{p}(\mathrm{C}=\mathrm{ci} \mid \mathrm{X}=\mathrm{xj})$ represents a conditional probability attribute $\mathrm{Xi}$ with a value of $\mathrm{xi}$ is given class $\mathrm{c}$, where in Naïve Bayes, class $\mathrm{C}$ is qualitative type while attribute $\mathrm{Xi}$ can be of qualitative or quantitative type.

- When the $X i$ attribute is of quantitative type then the chance $p(X=x i \mid C=c j)$ will be so small that it makes The probability equation is not reliable for quantitative type attribute problem. Then for dealing with quantitative attributes, there are several approaches which can be used like a normal distribution (Gaussian) (Syarli \& Muin, 2016)

Research by Alvina Felicia Watratan, Arwini Puspita \& Dikwan Moeis entitled "Implementation of Naive Bayes Algorithm to Predict Level Spread of Covid-19 in Indonesia" The main characteristic of this Naive Bayes Classifier is the assumption very strong (naive) will independence from each condition / event. explain Naive Bayes for each decision class, calculate the probability provided that the decision class is true, remembers vector object 


\section{Journal of Computer Networks, Architecture and High Performance Computing}

Volume 3, Number 2, July 2021

https://doi.org/10.47709/cnahpc.v3i2.1026
Submitted : 12 July 2021

Accepted : 24 July 2021

Published : 27 August 2021

information. This algorithm assumes that the object's attribute is independent. The probabilities involved in producing the final estimate is calculated as the amount frequency of "master" decision table (Alvina Felicia Watratan et al., 2020)

Research by Haditsah Annur entitled "Classification Of The Poor Using The Method Naive Bayes" Bayesian classification is a statistical classification that can be used to predict the probability of membership of a class. Bayesian classification is based on the theorem Bayes has similar classification capabilities to a decision tree and neural network. Bayesian classification is proven to have high accuracy and speed when applied to applications in databases with large data. The Bayes method is a statistical approach to perform inductive inference on classification problems. The first time we discuss about basic concepts and definitions in Bayes' theorem, then use this theorem to do classification in Data Mining(Annur, 2018)

Research by Naomi Siregar in their research "School Residents Regarding the Implementation of Distance Learning (PJJ)" Naïve Bayes is a simple classification method that is often used because it is easy to apply and has good results when applied in many cases. While the weakness of this method itself is the existence of assumptions or in other words conditions classes are independent of each other, so it is less accurate. As for practice, dependence exists between variable. For example hospital: patient, age, family, etc.(Chatrina, Siregar et al., 2020)

Research by Denny Nathaniel Chandra entitled "Classification Of Malang Radar Local News Using Naive Bayes Method With N-Gram Features" Use of Naïve Bayes Classifier in this research is able toproduce an accurate classification so that can be used as material for further research, Advantages of Naïve Bayes Classifier compared to other algorithms is on ability to classify documents with simplicity and speed computing but has computing high, the Naïve Bayes Classifier method too have a good performance against classification of document data contain both numbers and text. available datasets. This research propose a classification method with Naïve Bayes Classification (NBC) algorithm (Chandra et al., 2019).

Research by Bestari in their research "Academic Articles Classification Using Naive Bayes Classifier (Nbc) Method" The advantages of using the Naïve Bayes Classifier in document classification can be viewed from the process that take action based on pre-existing data. Therefore, document classification with this method can be adjusted according to the nature and needs of each person. like Articles scientific information on the website of the Sebelas Maret University Journal will be grouped according to the field of science. Based on the data obtained, only 10 fields of science are will be used. Grouping of scientific articles in this research apply the Naive Bayes Classifier classification method. (Bestari et al., 2018)

Wildan Budiawan Zulfikar \& Nur Lukman in their research "Comparison Of Naive Bayes Classifier With Nearest Neighbor For Identification Eye Disease" Naive Bayes Classifier is a method statistical classification that can be used for predict the probability of membership of a class. Naïve Bayes Classifier (NBC) is proven to have accuracy and high speed when applied to databases with large data. Nearest Neighbor is a comparison algorithm used to identification of eye disease. Naive Bayes Classifier and Nearest Neighbor will be combined in order to obtain results accurate identification. There are several aspects that be the material or criteria of the two algorithms namely the speed in the identification process (Zulfikar \& Lukman, 2016)

Research by Astia Syaputri, Erno Irwandi, \& mustakim with entitled "Naïve Bayes Algorithm for Classification of Student Major's Specialization" One of the algorithms used in classification is Naïve Bayes. The flow of the Naïve Bayes method is described in equations (Syaputri et al., 2020)

The formula used in Naïve Bayes

Bayesian probability is one way to overcome data uncertainty by using the Bayesian formula which is stated: "Equation (1) is"

$$
P(H \mid E)=\frac{P(E \mid H) \times P(H)}{P(E)}
$$

Information:

$\mathrm{P}(\mathrm{H} \mid \mathrm{E})$ : The probability that hypothesis $\mathrm{H}$ occurs if evidence $\mathrm{E}$ occurs.

$\mathrm{P}(\mathrm{E} \mid \mathrm{H})$ : Probability of emergence of evidence $\mathrm{E}$, if hypothesis $\mathrm{H}$ occurs.

$\mathrm{P}(\mathrm{H})$ : The probability of hypothesis $\mathrm{H}$ regardless of any evidence. 


\section{Journal of Computer Networks, Architecture and High Performance Computing}

Submitted : 12 July 2021

Volume 3, Number 2, July 2021

https://doi.org/10.47709/cnahpc.v3i2.1026

$\mathrm{P}(\mathrm{E})$ : The probability of evindece $\mathrm{E}$ regardless of anything.

Or you can also use the following formula if there is Single Evidence E and Multiple Hypotheses H: "Equation (2) is "

$$
\mathrm{P}(\mathrm{Hi} \mid \mathrm{E})=\frac{\mathrm{P}(\mathrm{E} \mid \mathrm{Hi}) \times(\mathrm{Hi})}{\sum_{\mathrm{k}=1}^{\mathrm{n}} \mathrm{P}(\mathrm{E} \mid \mathrm{Hi}) \times \mathrm{P}(\mathrm{Hi})}
$$

Information :

$\mathrm{P}(\mathrm{Hi} \mid \mathrm{E})$ : The probability that the hypothesis Hi occurs if the evidence E occurs. 53

$\mathrm{P}(\mathrm{E} \mid \mathrm{Hi})$ : The probability of the emergence of evidence $\mathrm{E}$ if the hypothesis Hi occurs.

$\mathrm{P}(\mathrm{Hi})$ : The probability of the hypothesis is $\mathrm{Hi}$, regardless of any evidence.

$\mathrm{n}$ : The number of hypotheses that occur.

There is also a Bayes Theorem formula if there is Double Evidence E and Double Hypothesis H: "Equation (3) is"

$$
\mathrm{P}(\mathrm{Hi} \mid \mathrm{E} 1 \mathrm{E} 2 \ldots \mathrm{En})=\frac{\mathrm{P}(\mathrm{E} 1 \mid \mathrm{Hi}) \times \mathrm{P}(\mathrm{E} 2 \mid \mathrm{Hi}) \times \ldots \times \mathrm{P}(\mathrm{Em} \mid \mathrm{Hi}) \times \mathrm{P}(\mathrm{Hi})}{\sum_{\mathrm{k}=1}^{\mathrm{P}} \mathrm{P}(\mathrm{E} 1 \mid \mathrm{Hk}) \times \mathrm{P}(\mathrm{E} 2 \mid \mathrm{Hk}) \times \ldots \times \mathrm{P}(\mathrm{Em} \mid \mathrm{Hk}) \times \mathrm{P}(\mathrm{Hk})}
$$

\section{METHOD}

Research Framework The research framework is the sequence carried out in the study. So that the steps taken by the author in this design do not deviate from the main discussion. The research framework that the author did in this research will be described in Fig. 3 as follows:

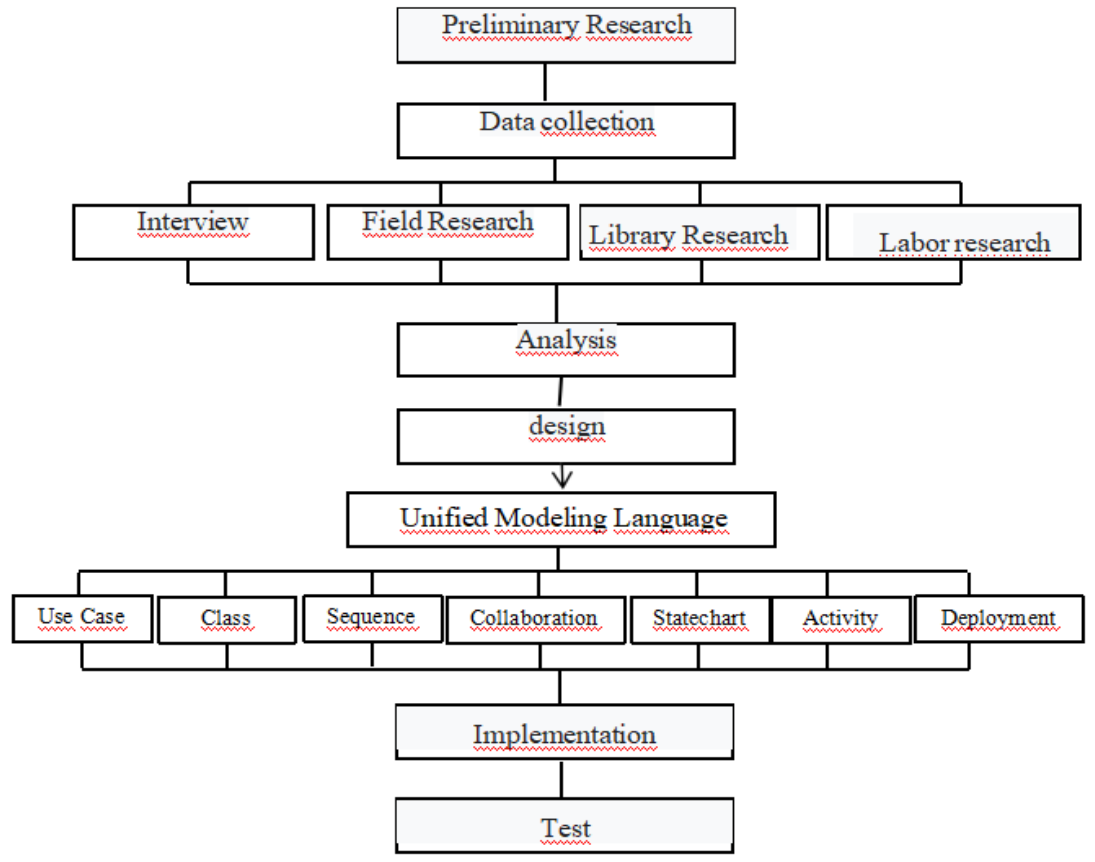

Fig 1. Research Framework

At this stage of research contains an explanation of the research framework above. Where the research framework contains preliminary research, data collection, analysis, design, implementation, and testing. In To conduct research, a method is needed to conduct the research. The research method is the method / activity of 


\section{Journal of Computer Networks, Architecture and High Performance Computing}

Submitted : 12 July 2021

Volume 3, Number 2, July 2021

Accepted : 24 July 2021

https://doi.org/10.47709/cnahpc.v3i2.1026

carrying out research according to steps that have been arranged systematically and logically so that they can used as a clear and easy guide to solving a problem.

\section{RESULT}

Testing The Interface on The Expert System.

Home Page This page is the initial display of the expert system application, which can be seen in the following figure.

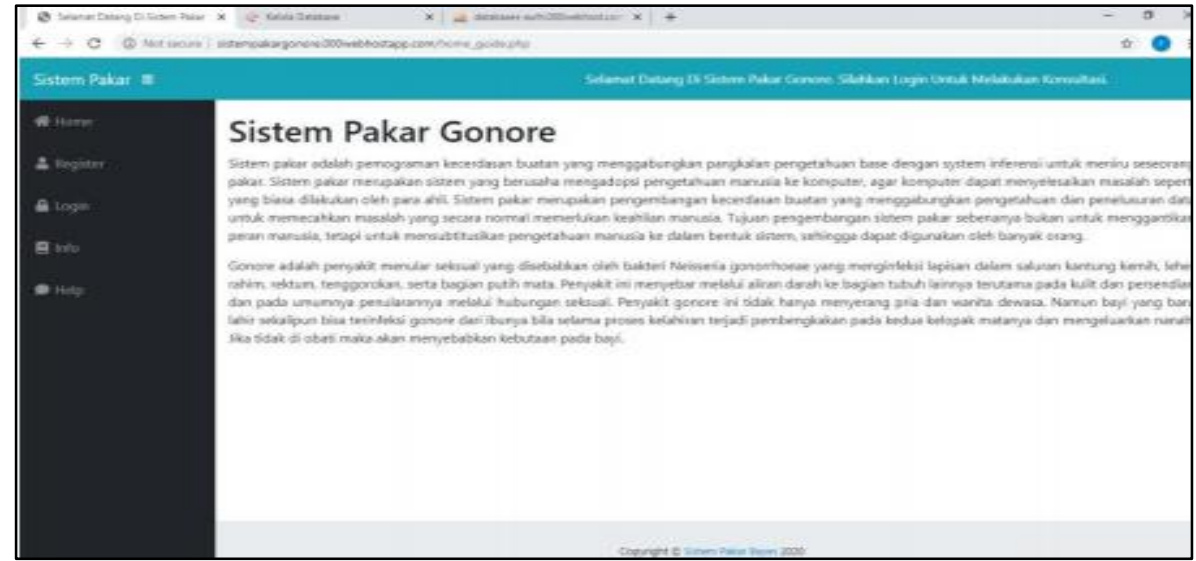

Fig. 2 Main page

\section{Registration Page}

This page is a registration page display can be seen in the following image.

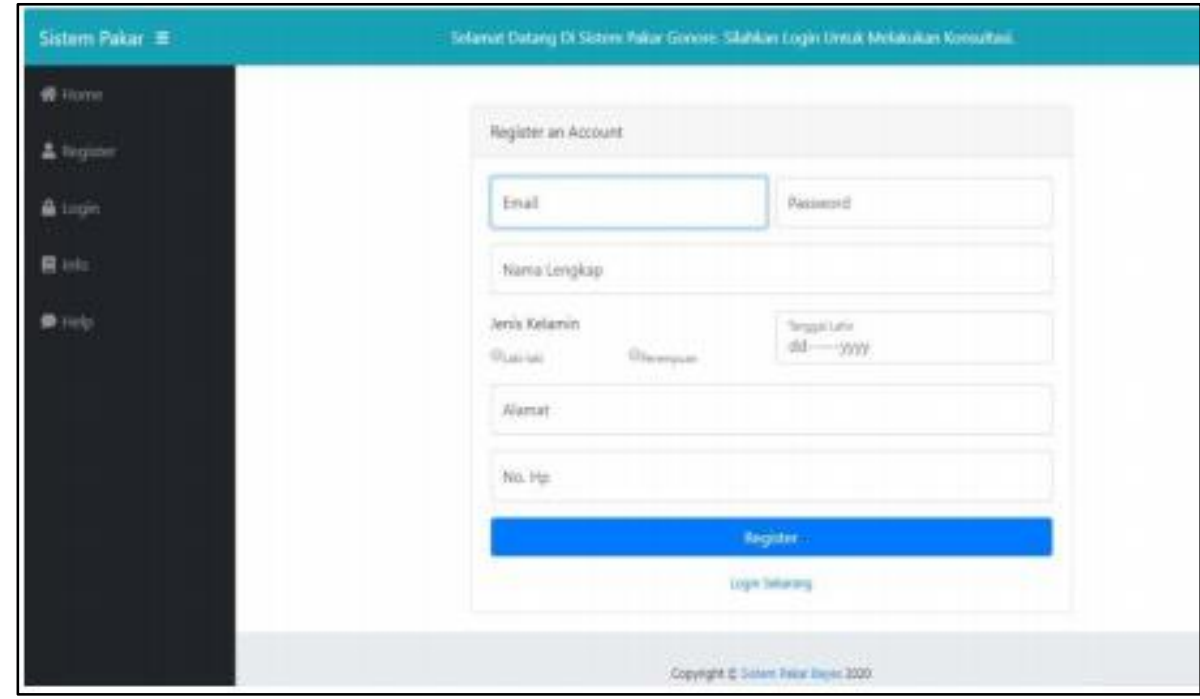

Fig. 3 Registration Page

The page above is a register page display, it works for users who are not yet members. That is by filling in the data on each form available.

\section{Login Page}

This page is a login page display can be seen in the following image. 


\section{Journal of Computer Networks, Architecture and High Performance Computing}

Volume 3, Number 2, July 2021

https://doi.org/10.47709/cnahpc.v3i2.1026
Submitted : 12 July 2021

Accepted : 24 July 2021

Published : 27 August 2021

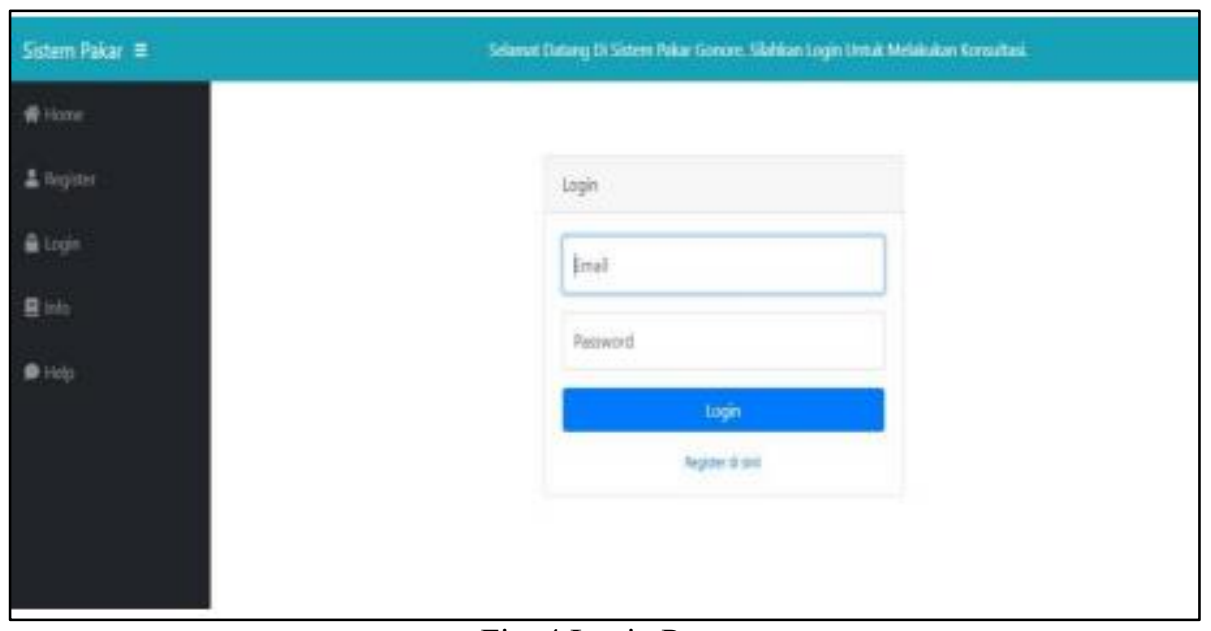

Fig. 4 Login Page

The picture above is a login page display, where the user must enter a username and password so that the user can enter the expert system.

\section{Homepage}

This page is a member's home page display after entering the expert system can be seen in the following image.

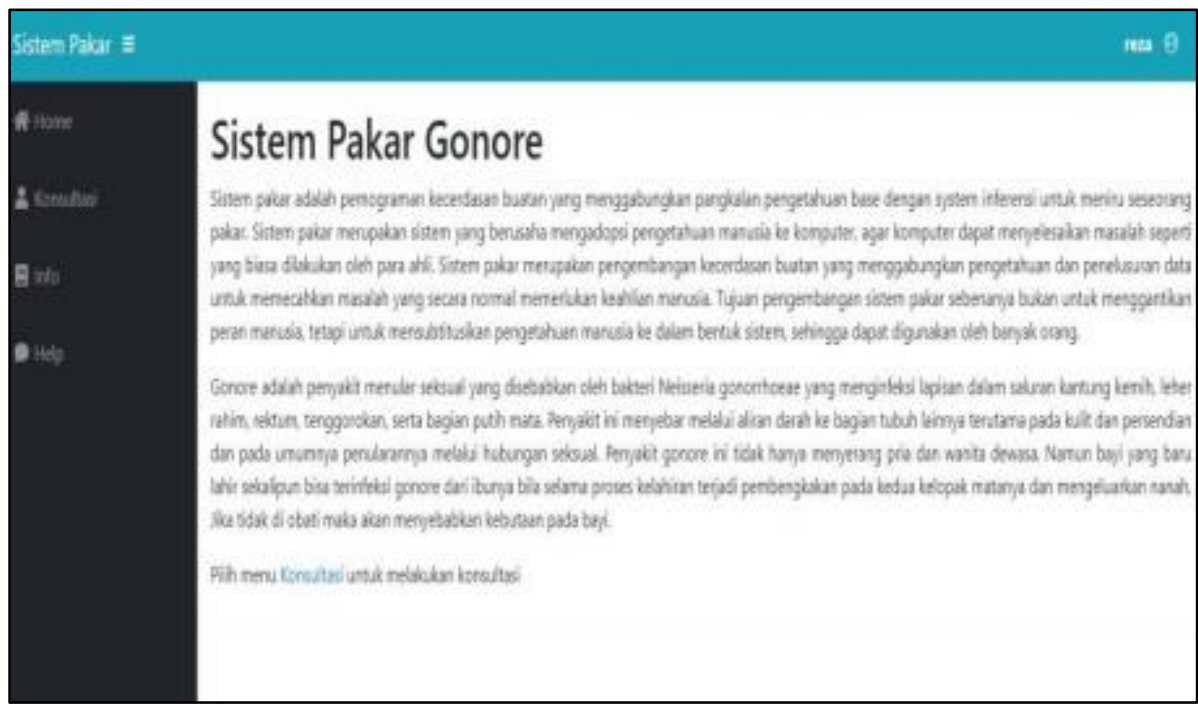

Fig. 5 Homepage

\section{Consultation Advanced Page}

This page is a display of the consultation page in the expert system which can be seen in the following figure. 


\section{Journal of Computer Networks, Architecture and High Performance Computing}

Volume 3, Number 2, July 2021

https://doi.org/10.47709/cnahpc.v3i2.1026
Submitted : 12 July 2021

Accepted : 24 July 2021

Published : 27 August 2021

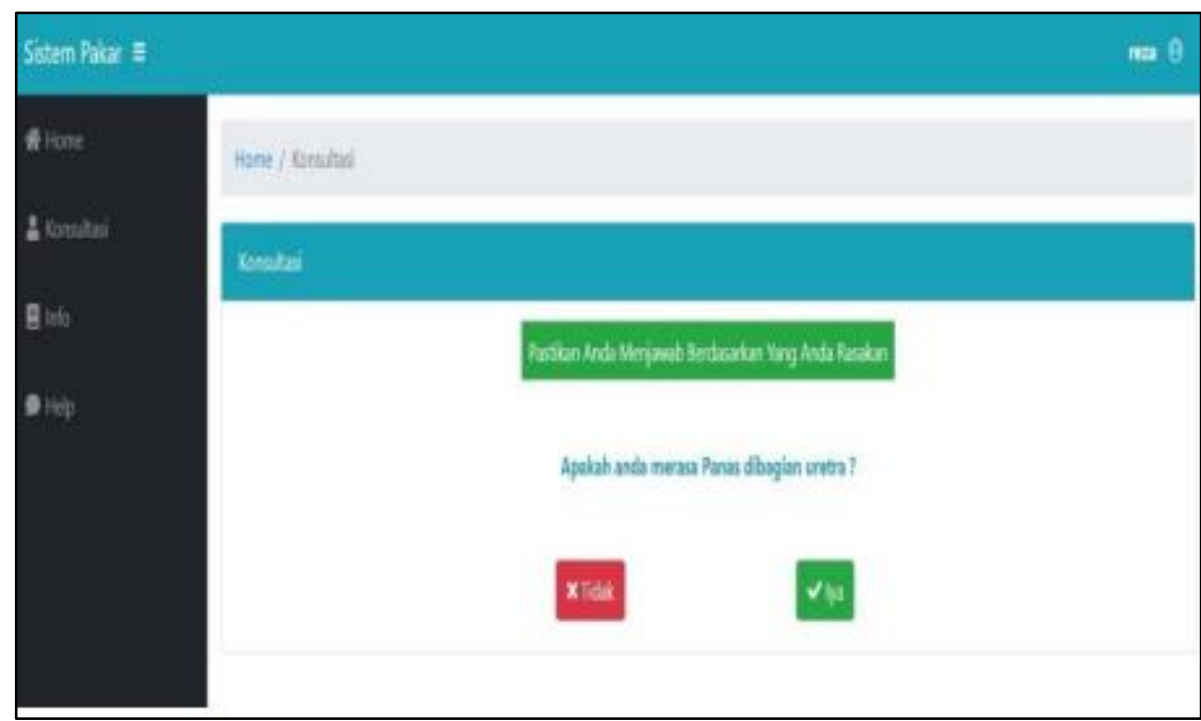

Fig. 6 Consultation Advanced Page

The picture above is a consultation page display, on this page members answer questions from the system with "yes or no" answers. After answering, the question will move on to the next question.

\section{Consultation Results Page}

This page is a display of the consultation results page which can be seen in the following image. 


\section{Journal of Computer Networks, Architecture and High Performance Computing}

Volume 3, Number 2, July 2021

https://doi.org/10.47709/cnahpc.v3i2.1026
Submitted : 12 July 2021

Accepted : 24 July 2021

Published : 27 August 2021

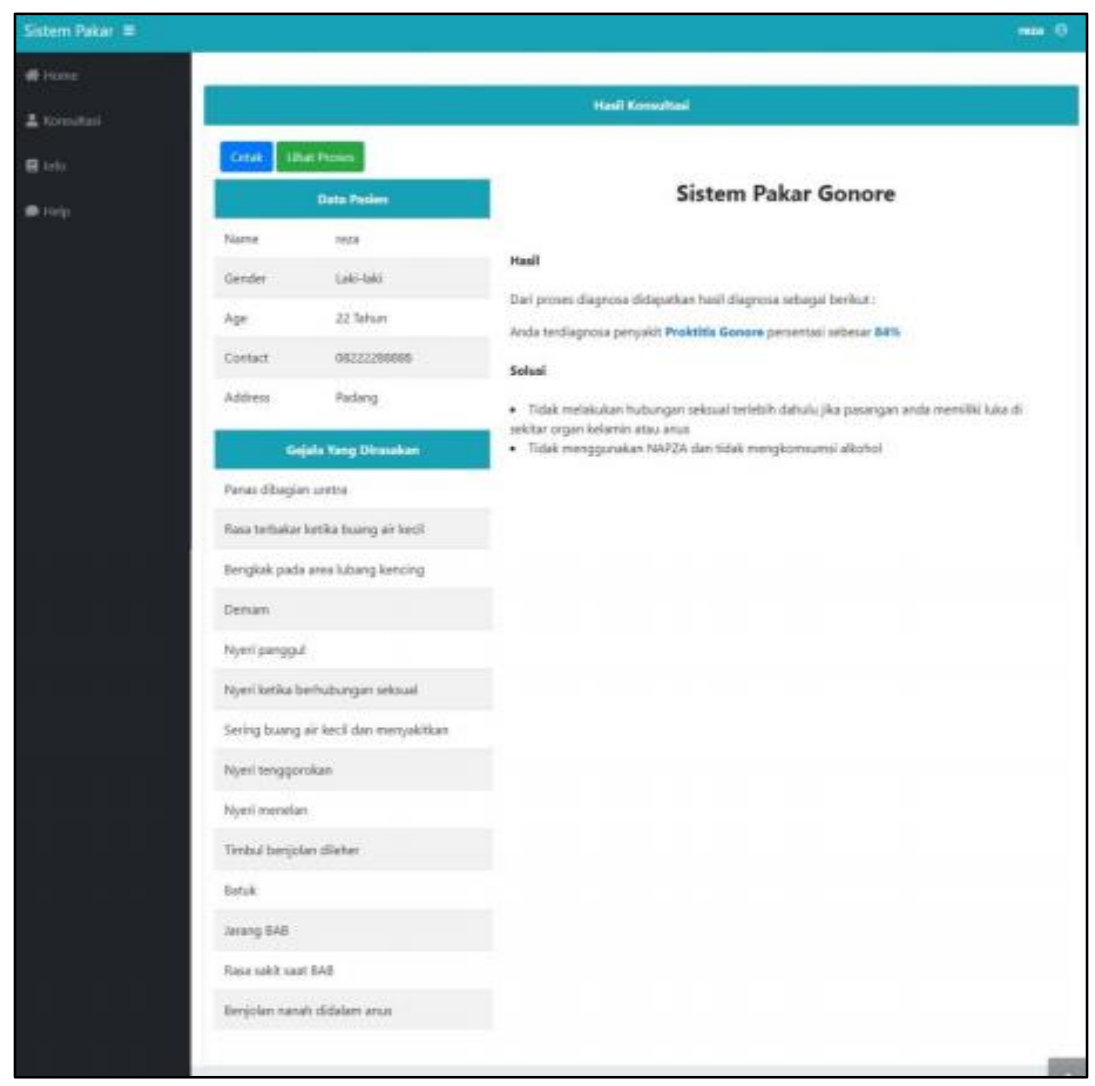

Fig. 7 Consultation Page

The picture above is a display of the results of the consultation of members who conduct consultations, members can print and see the search process.

\section{Print Results Page}

This view is a printed consultation page view can be seen in the following image.

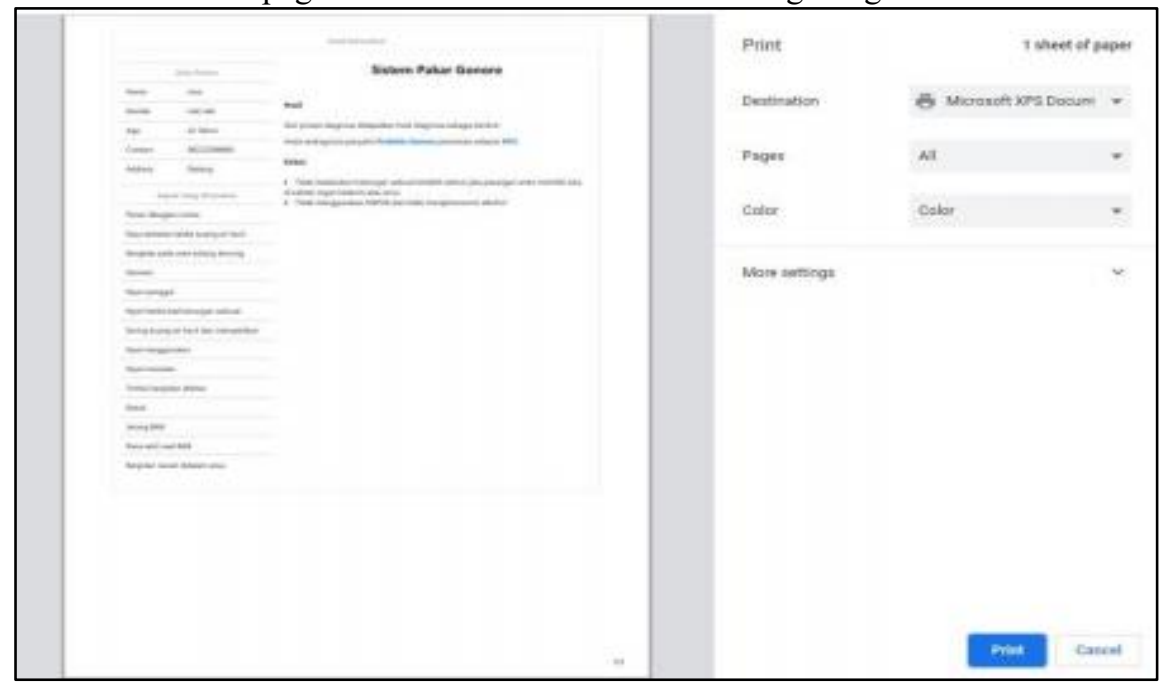

Fig. 8 Print Results Page 


\section{Journal of Computer Networks, Architecture and High Performance Computing}

\section{Admin Home Page}

This page is the admin home page view which can be seen in the following image.

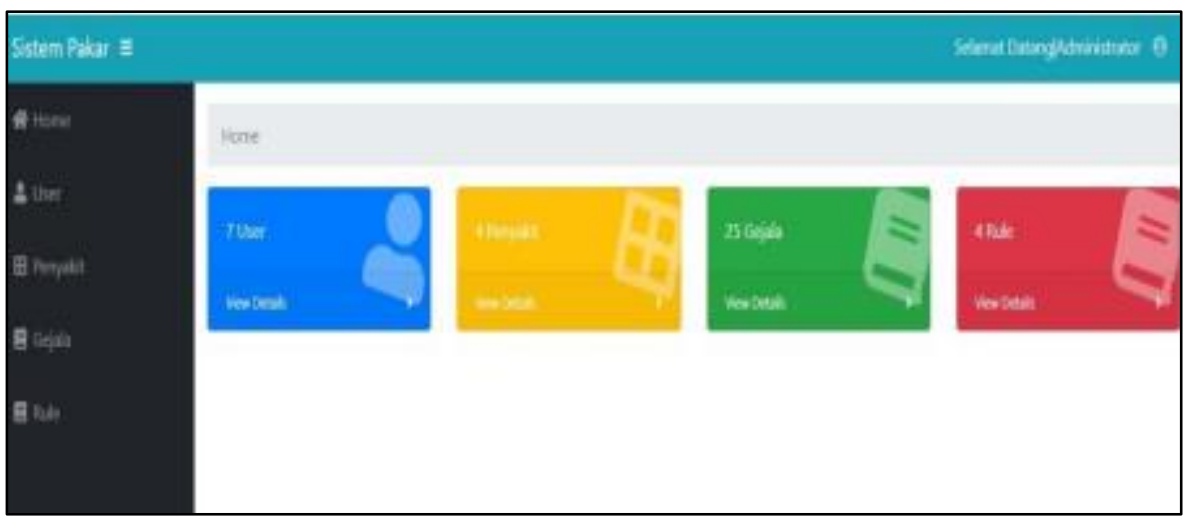

Fig. 9 Admin Home Page

\section{Disease Data Page}

This page is a disease data page view can be seen in the following image.

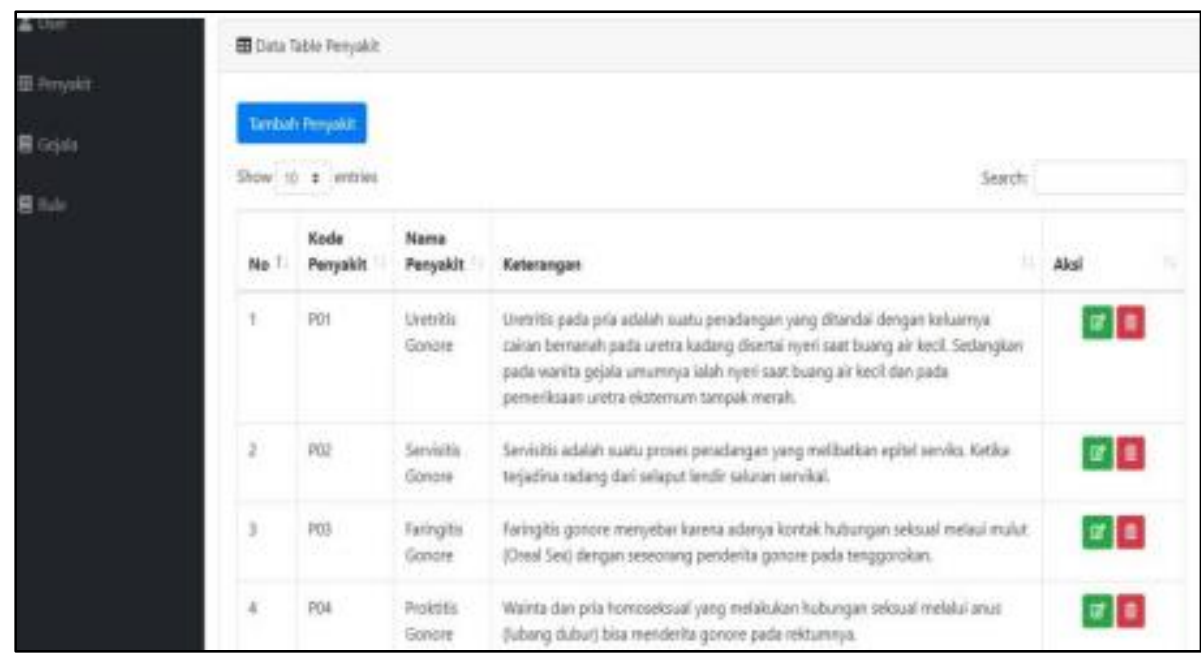

Fig. 10 Disease Data Page

The image above is a display of the disease data page. Admin can manage existing diseases, add, edit and delete diseases.

\section{Symptom Data Page}

This page is a symptom data page display which can be seen in the following image. 


\section{Journal of Computer Networks, Architecture and High Performance Computing}

Volume 3, Number 2, July 2021

https://doi.org/10.47709/cnahpc.v3i2.1026
Submitted : 12 July 2021

Accepted : 24 July 2021

Published : 27 August 2021

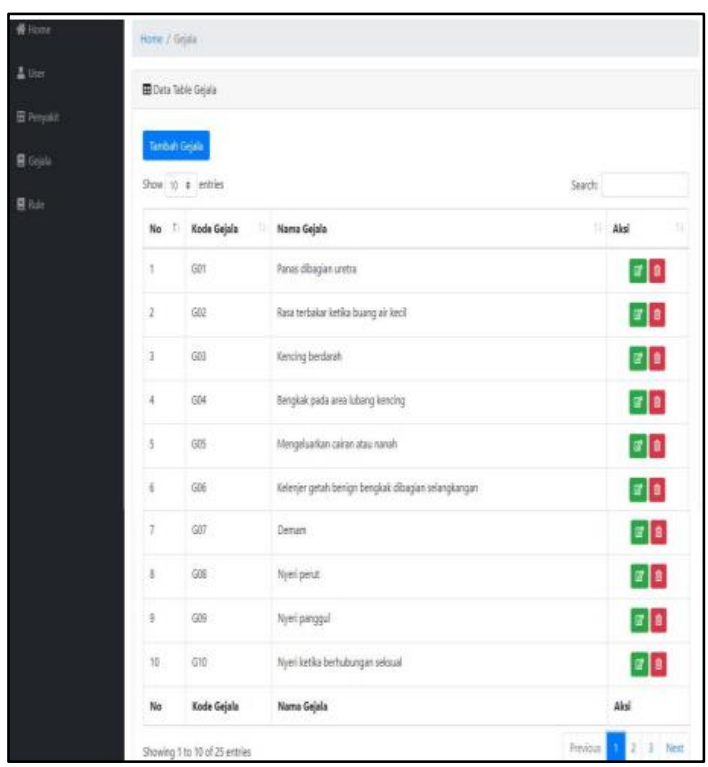

Fig. 11 Symptom Data Page

\section{CONCLUSION}

From the description of the problem above, as well as based on the analysis of the existing chapters, the following conclusions are drawn: By using this expert system application, it can provide information to the public and make it easier for the public to better recognize Gonorrhea and can handle problems based on the expertise of doctors who are experts in their fields. So that people do not need to directly consult a doctor. The community can obtain prevention solutions from the diagnosis obtained from the results of consultations on the expert system application. This expert system can help the community in diagnosing Gonorrhea. Help anticipate disease in the community. By using the Gonorrhea expert system application, the general public will know and pay more attention to the dangers of Gonorrhea.

\section{REFERENCES}

Adityo, R. D., \& Miawarni, H. (2017). Implementation of Naive Bayes Classifier Algorithm to Evaluation in Utilizing Online Hotel Tax Reporting Application. VOLT : Jurnal Ilmiah Pendidikan Teknik Elektro, 2 (2), 125. https://doi.org/10.30870/volt.v2i2.2049

Alvina Felicia Watratan, Arwini Puspita. B, \& Dikwan Moeis. (2020). Implementasi Algoritma Naive Bayes Untuk Memprediksi Tingkat Penyebaran Covid-19 Di Indonesia. Journal of Applied Computer Science and Technology, 1(1), 7-14. https://doi.org/10.52158/jacost.v1i1.9

Annur, H. (2018). Klasifikasi Masyarakat Miskin Menggunakan Metode Naive Bayes. ILKOM Jurnal Ilmiah, 10(2), 160-165. https://doi.org/10.33096/ilkom.v10i2.303.160-165

As’ad, B. (2016). Prediksi Kehadiran Menggunakan Metode Klasifikasi Naïve Bayes, One-r, Decision Tree. Jurnal Penelitian Komunikasi Dan Opini Publik, 20(1), 124041.

Bestari, D. P. B., Saptono, R., \& Anggrainingsih, R. (2018). Academic Articles Classification Using Naive Bayes Classifier (Nbc) Method. Jurnal Ilmiah Teknologi Dan Informasi, 7(2), 74-81.

Chandra, D. N., Indrawan, G., \& Sukajaya, I. N. (2019). Klasifikasi Berita Lokal Radar Malang Menggunakan. $10(2), 11-19$.

Chatrina, Siregar, N., Ruli, A, Siregar, R., \& Yoga, Distra, Sudirman, M. (2020). Implementasi Metode Naive Bayes Classifier (NBC) Pada Komentar Warga Sekolah Mengenai Pelaksanaan Pembelajaran Jarak Jauh (PJJ). Jurnal Teknologia, 34(1), 102-110. https://aperti.e-journal.id/teknologia/article/view/67

Fadillah, A. P., \& Hardiyana, B. (2018). Penerapan Naïve Bayes Classifier Untuk Pemilihan Konsentrasi Mata Kuliah. Jurnal Teknologi Dan Informasi, 8(2). https://doi.org/10.34010/jati.v8i2.1039 


\section{Journal of Computer Networks, Architecture and High Performance Computing}

Submitted : 12 July 2021

Volume 3, Number 2, July 2021

https://doi.org/10.47709/cnahpc.v3i2.1026

Hairani, H., \& Innuddin, M. (2020). Kombinasi Metode Correlated Naive Bayes dan Metode Seleksi Fitur Wrapper untuk Klasifikasi Data Kesehatan. Jurnal Teknik Elektro, 11(2), 50-55. https://doi.org/10.15294/jte.v11i2.23693

Karunia, S. A., Saptono, R., \& Anggrainingsih, R. (2017). Online New Classification Using Naive Bayes Clasifier with Mutual Information for Featur Selection. Jurnal Ilmiah Teknologi Dan Informasi, 6(1), 10-15. https://www.researchgate.net/publication/319963217\%0AOnline

Octiara, D. L., \& Ungu, B. (2018). Electrochemical Biosensor Sebagai Diagnostik Terbaru Terhadap Penyakit $\begin{array}{llll}\text { Gonore. } & \text { Jurnal } & \text { 255-260. }\end{array}$ https://juke.kedokteran.unila.ac.id/index.php/majority/article/view/2087

Pitasari, D. A., \& Martodiharjo, S. (2019). Studi Retrospektif: Profil Infeksi Gonore ( Retrospective Study: Gonorrhoeae Profile ). Ilmu Kesehatan Kulit Dan Kelamin - Periodical of Dermatology and Venereology, $31(1), 41-45$.

Prayoga, N. D., Hidayat, N., \& Dewi, R. K. (2018). Sistem Diagnosis Penyakit Hati Menggunakan Metode Naïve Bayes. Jurnal Pengembangan Teknologi Informasi Dan Ilmu Komputer (J-PTIIK), 2(8), 2666-2671.

Syaputri, A. W., Irwandi, E., \& Mustakim, M. (2020). Naïve Bayes Algorithm for Classification of Student Major's Specialization. Journal of Intelligent Computing \& Health Informatics, 1(1), 17. https://doi.org/10.26714/jichi.v1i1.5570

Syarli, S., \& Muin, A. (2016). Metode Naive Bayes Untuk Prediksi Kelulusan (Studi Kasus: Data Mahasiswa Baru Perguruan Tinggi). Jurnal Ilmiah Ilmu Komputer, 2(1), 22-26.

Zulfikar, W. B., \& Lukman, N. (2016). Perbandingan Naive Bayes Classifier Dengan Nearest Neighbor Untuk Identifikasi Penyakit Mata. Jurnal Online Informatika, 1(2), 82-86. https://doi.org/10.15575/join.v1i2.33 